\title{
Balancing the transcendence and immanence of God in Nürnberger's theology
}

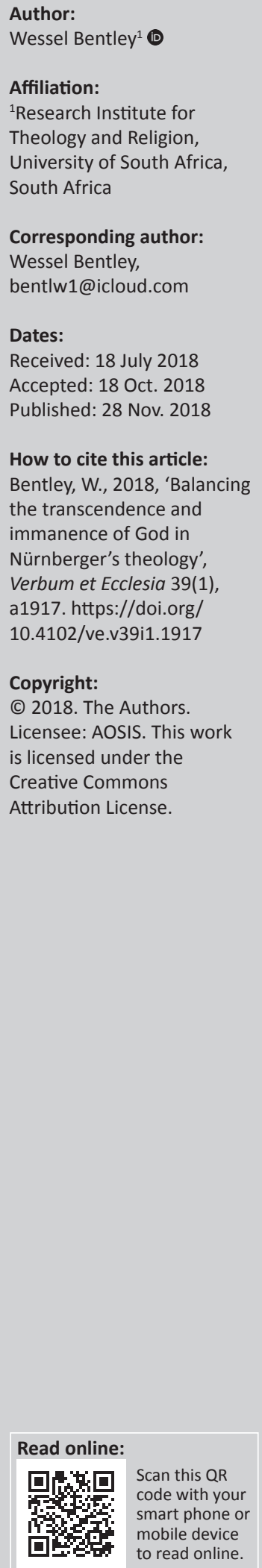

\section{Author:}

Affiliation:

${ }^{1}$ Research Institute for University of South Africa,

Corresponding author: Wessel Bentley,

Dates: Accepted: 18 Oct. 2018

How to cite this article: Bentley, W., 2018, 'Balancing immanence of God in Nürnberger's theology', 1917. https://doi.org/

Copyright:

C 2018. The Authors. is licensed under the Creative Commons

\begin{abstract}
Klaus Nürnberger has provided an invaluable contribution to theology over the course of his career, and he continues to do so. His recent writings focus on a model of theology that takes seriously the truth claims made by the natural sciences. This article investigates Nürnberger's understanding of God in the context of the science-religion conversation. It particularly focuses on how Nürnberger describes the immanence and transcendence of God.

Intradisciplinary and/or interdisciplinary implications: This article provides an investigation of Klaus Nürnberger's doctrine of God, with special reference to transcendence and immanence. It engages natural science, theology and philosophy as its conversation partners.
\end{abstract}

\section{Introduction}

The story is told of a systematic theology professor who started his first-year class by making the following statement: 'God does not exist'. He then sat down and listened to his students debating this contentious claim. We can imagine the conversation fluctuating between those who proposed God as an ontological being, while others argued for a more metaphysical entity. At the end of the lesson, the professor stood up and concluded: 'God does not exist; God is'. In this foundational premise to the doctrine of God, the professor alluded to one of the most profound struggles in Christian theology, namely, the attempt to 'locate' God. It is only by 'locating' God that we can try to understand how the rest of the doctrines play out.

Where is God? Is God here or is God beyond here? Is God immanent or is God transcendent? Is God located in time and space or is God free from these limitations of physical reality? Are these options mutually exclusive? Depending on where God is situated, the way we answer questions on topics such as free will, theodicy, sin, incarnation, salvation, eschatology (and the list goes on) will determine the image of the God we propose in our theology. This article will not focus on these latter problems; they are secondary to the problem of 'finding God'. Instead, this article will focus on where God is to be 'found' in Klaus Nürnberger's theology, with specific reference to God's transcendence and immanence.

\section{The problem of context}

Over the last few decades, Klaus Nürnberger's contribution to Christian theological discourse focused on our ability to speak about God. More recently his emphasis has shifted to speaking about God in an age that has seen an exponential advancement in science and technology. With our unyielding dependence on science and technology to gain insights into claims on truth, reality and the experience of life, it appears as if religion ${ }^{1}$ is becoming less informative (and informed) in these areas. The consequence is that it is becoming increasingly difficult to speak about God, religious truths and faith claims in a world dominated by ontologies (What is there?) and epistemologies (How do we know what is there?) grounded in the natural sciences.

It comes as no surprise that claims are made, proposing that the old knowledge of religion (and metaphysics) should be exchanged for the new knowledge unearthed by empirical science (see Dawkins 2006:309-340; Durand 2017). ${ }^{2}$ If asked where God is located in the natural sciences, Dawkins and company relegate God to the human imagination - 'to denote a supernatural creator

1.Klaus Nürnberger is a Christian theologian. In the context of this article, Nürnberger's and the author's use of 'religion' refers to the Christian religion as a backdrop. God-talk and talk of transcendence nevertheless are not unique to the Christian religion; so although the Christian religion is foundational in this argument, it also argues that God should not be limited only to the understanding of the Christian faith.

2.Dawkins argues that science provides the only credible instruments for humanity to understand our surroundings, and then by default to understand ourselves. Religion, in his view, is only a stumbling block in 'facing the facts' provided by science. Durand argues that it is easy for human beings to jump to religious and metaphysical conclusions. Science, when done well, not only challenges the proposed assumptions, but provides an alternative truth than negates our religious and metaphysical assumptions. 
that is "appropriate for us to worship"' (Dawkins 2006:13). Even in this quote, God is positioned. The 'denoted God' (a figment of our imagination stemming from a need to answer existential questions) is 'supernatural' (outside the realm of physics; as creator, distinct from creation and therefore not part of the natural order governed by the laws of physics). God is thus purely transcendental, even though ironically God exists as a product of our thinking. Needless to say, from this perspective, religion and science cannot converse as equal partners because it appears as if religion focuses exclusively on that which is outside the parameters of scientific exploration.

Nürnberger contests the position of a mutually exclusive relationship between science and religion but does not dismiss science's claim out of hand. He asks whether there is a way we can talk about God while holding to the truth claims made by both science and religion. To him, on the one side it would be ridiculous for any person with a religious inclination to rubbish science in favour of their religious belief systems. Although the alternative side of the argument is certainly plausible, it would be short-sighted of science to exclude religion altogether. To the religious fundamentalist, it should be said that the natural sciences have assisted us tremendously in understanding various aspects of our reality. Science has helped us to understand disease, to advance transport, manufacturing, knowledge dissemination and it even opened the possibility to explore the far expanses of space. Our lives are shaped and are being shaped by science and technology - this is beyond dispute. Is God at all to be found in this science-driven context? Before getting to the question of God and locating God, according to Nürnberger, a differentiation first needs to be made between the nature of enquiry found in science and religion. As stated by Conradie (2012) and Nürnberger (2011a):

Science is about immanence; faith is about transcendence. Science is about knowledge; faith is about commitment. A fully explained universe is meaningless. A profoundly meaningful life can be riddled with untenable assumptions. (p. 129; p. 47)

Although science can tell us much about our physical reality, it cannot answer all questions. For example, science cannot conclusively address questions of meaning, morality and values. In the same way, religion may tell us about meaning, but when it does not take into account the context in which it operates, it dooms itself to the outskirts of irrelevance. Now, it may appear as if Nürnberger is suggesting a similar model to that of Gould's non-overlapping magisteria (NOMA) (Gould 2002), but this is not the case. Where Gould separates religion and science as non-intersecting tools, Nürnberger places both science and religion in one context, in what he calls 'experiential realism' (Nürnberger 2016a). It is in this context of experiential realism that science and religion operate in tandem to address the questions of life comprehensively. We need scientific knowledge to understand the world we live in and we need religion to help us understand values, meaning and purpose so that we can live responsibly in this world. As Conradie (2012:127) puts it, science needs "'best faith" to be responsible, while faith needs "best science" to be credible' (Conradie 2012:127).

\section{Experiential realism}

Experiential realism 'tries to understand how the reality that we experience is actually put together, how it actually functions and how it can be transformed and utilised to our advantage' (Nürnberger 2016a:51). Experiential realism does not claim that we can have an objective bird's eye-view of reality, but states that our context, our lived reality, is subjective and can only be understood and communicated from this vantage point. Science and religion both operate within this context. So, the question Nürnberger asks about where God is located is neither 'Where is God in science?' nor 'Where is God in religion?', but 'Where is God in experiential realism?'

If we were to pursue the language of 'immanence' and 'transcendence' in experiential realism, then regarding immanence we may still think that science is best situated to deal exclusively with 'what is' while leaving no room for the possibility or relevance of transcendence. This is not the case. Whenever there is immanence, transcendence is sure to be either overtly claimed or subtly assumed. Conradie argues that although we may not comprehend what is in the transcendent, it is the transcendent that allows us to appreciate the immanent in a new light (Conradie 2013), very much like the prospect of a relaxing holiday makes the journey to the holiday destination both exciting and bearable. Our experience of the transcendent is always immanent (Conradie 2013:41; Hick 1997:57), located within the context of Nürnberger's experiential realism. The journey of life, truth-seeking and the understanding of reality are about the journey itself (immanence), not the destination (transcendence), but it is the destination that allows us to appreciate the journey.

Perhaps the problem with religion's apparent irrelevance in the immanent is that it tends to promote an idea of God who is located exclusively in the transcendent. It is no wonder that atheistic science tends to see religion as bungling in hypotheticals. Nürnberger agrees that a God located squarely in the transcendent is problematic. He gives the following reasons (Nürnberger 2011b:3):

- A purely transcendental God is based on an image of God proposed by ancient traditions with archaic world views that do not have the benefit of having integrated recent scientific discoveries. God, for them, was 'up there' and could not be of the same substance or essence of what is 'here below'. We need to move away from the ancient Israelite and Hellenistic notions of God as 'unmoved maker' (Nürnberger 2015:104).

- With our understanding of the universe, we know that there is neither a simple 'up there' nor a 'here below' and hence there is no evidence for the so-called transcendent space that God occupies. 
- Our experience of reality is dependent, it is believed, on the will and plans of a personal God. A God who is purely transcendental cannot interact with immanent beings, confined by the limitations of time and space.

For Nürnberger, to draw absolute distinctions between immanence and transcendence makes it impossible to speak credibly about God or to adhere to scientifically acceptable faith claims in the context of experiential realism. Experiential realism is all that we have, the basis on which our knowledge of this world, and of God, is deduced. This does not imply that God is to be reduced to the material or to the subjective experiences of humanity. To do so would be to negate transcendence and to hold only to immanence as the source of experiential realism (Nürnberger 2010:113).

The other alternative would be to read transcendence into the immanent, leading to the allure of pantheism. This too is problematic to Nürnberger on two counts. Firstly, such a position makes it impossible for humanity to proclaim a 'personal relationship with God'. The relationship with a God captured in the confines of the immanent is nothing less than having a projected relationship with the divine through a tree or a stream or another physical object. Although there is something awe-inspiring about being in nature, if God were captured by the objects of our awe, then would it be realistic to assume that such a God could convict us of our sin, or be moved to 'anger' through our reckless actions? Can such a God truly comfort the afflicted or console the desperate? God must be more than this. Secondly, it would not be far-off for humanity to develop a sense of entitlement, thinking that as the highest evolved form of life on earth, it leads to the conclusion that the rest of creation falls under our dominion (Nürnberger 2016a:9). There is an inherent need for God to be more than the immanent, but conversely not to be confined to the transcendent.

So, where is God? In addressing the question, Nürnberger poses another question about the nature of experiential realism. He asks whether we 'experience and explore [a reality] closed in upon itself-self-generating, self-sustaining, self-destructing - or is it derived from, and dependent on a transcendent Source and Destiny?' (Nürnberger 2011b:1). If we were to answer 'yes' to the first option, then humanity can see itself as the pinnacle of evolution and has no need for an external God; either God does not exist, or God is confined to the closed system. If it is the second option (of Nürnberger's question, referring to a purely transcendental God), then the conclusion would be that we have a scenario where 'internal' and 'external' powers are at work, rendering the natural processes of physical reality subjective and meaningless in light of the external 'authority'. This is untenable from a scientific perspective. Arguing via negativa, to Nürnberger, God is neither locked in the immanent nor is God to be found only in the transcendent. Nürnberger then offers another option: God as ultimate Source and Destiny in experiential realism.

\section{God as ultimate Source and Destiny}

Perhaps another metaphor (flawed, as all metaphors are) would assist us here. Nürnberger himself contends that when we speak about transcendence and also, God, that we can only express our understanding in the form of ' ... metaphors, symbols, parables and myths' (Nürnberger 2012:61). Imagine a piece of string. It has two points: a beginning and an end. The string encompasses the beginning, the end and everything in between. It cannot be without either end, and neither can either end exist without that which is between. The string, along with its two points, makes a comprehensive whole.

In Nürnberger's estimation, God is the ultimate Source (beginning) and ultimate Destiny (end) of experiential realism (the string). To be noted is that God is not confined to the 'ends', which mark the liminal point between immanence and transcendence. Neither is God solely located in the immanent (the string). The ends form part of the string, and the string gives the possibility for the existence of both ends. In the same way, God as ultimate Source and Destiny is intimately interwoven in the immanence of experiential realism, but does so also as its transcendent source and destiny. Experiential realism exists because God is.

God as the ultimate Source and Destiny does not refer to God as encompassing predetermined points, but to a projection of 'what is' and 'what ought to be' (Nürnberger 2016a:16). We find a very similar portrayal of God and creation in Moltmann's theology. To Moltmann, God is not only the origin as the source of the creative activity of the universe but also the destiny of the universe by drawing all things to Godself (Moltmann 1985:5, 1996:232, 262). The difference between Nürnberger and Moltmann is that where Moltmann suggests a return of the created realm to the intended good which God proclaimed (as reflected) in Genesis 1 and 2, to Nürnberger there is no so-called return for creation to any previous state. Instead, as the Source, God forms part of the creative potential of the universe, gives expression to this creative potential through the laws of physics and encapsulates the transcendent destiny of the universe through its continuous development. This description of God may make theological sense, but does it speak to the natural sciences?

To speak about God in scientific terms, Nürnberger draws on the concept of emergence and complexity theory (Nürnberger 2011b:3-4). First, agreeing with Kauffman (2008:284-285; Nürnberger 2011b:11), Nürnberger suggests that God is in and part of the natural creativity of the universe. This means that God is not locked in only one level of complexity, namely, that of human consciousness and awareness, but that God (or Kauffman's 'the sacred') permeates through the fine balance of integration between different levels of complexity as found in the layered manifestation of emergence theory. God is part of/in/through the complexity of this multi-layered reality of emergent strata (Nürnberger 2016a:7). Emergence itself points to the existence of transcendence in immanence within the ambit of physics, for it continuously points to the 
appearing of 'new vistas' (Nürnberger 2010:115-116) of complexities. This makes the creative potential within the universe infinitely surprising.

'All levels of complexity belong to nature' (Nürnberger 2016a:21). To Nürnberger this is a fact. There is no evidence to suggest that anything participates in, influences or interferes with the different processes of divergent levels of complexity, manifesting as distinctly 'un-natural' or extraordinary to that which we perceive in nature. To this end, the natural sciences, I assume, can agree with what Nürnberger suggests. But theologically, if God can be described as the creative potential and creative reality of and in the universe, then this claim has consequences for how we interpret God's immanence and transcendence.

Nürnberger (2016c) states the following:

... being transcendent, God cannot be real in the sense that calcium, cats or synaptic networks are real. God cannot be part of immanent reality among other parts, with whom 'he' could compete or cooperate at the same level of causation. Rather, God works through all these entities and processes as their transcendent Source and Destiny. (p. 2)

By this description, Nürnberger avoids God being locked in immanence, or experiential realism; this is the transcendent nature of God - that God does not exist. God is not reduced to matter. God is, and because God is, the emergent strata of complexity makes it possible for conscious beings to be aware of, and come to know God (Nürnberger 2017:5). Life, consciousness and awareness, all that we claim in experiential realism that enables us to be human, are gifts that form part of the context of emergent complexity (Veldsman 2013:32).

\section{Why faith (religion)?}

It would not be difficult for the natural sciences to concur with such a definition of God. Science itself stands in awe of the natural processes that manifest through emergence and complexity theory. If this is God, then God is in science and underwrites scientific epistemology. Why do we then need faith? Why even refer to God?

In Nürnberger's view, the word 'God' can be nothing more than our limited word for the ultimate Source, Processes and Destiny encapsulated in the conglomerate of all levels of complexity (Nürnberger 2016a:2). God is not outside the processes of a complex universe, manifesting as an autonomous entity, and neither is God locked into any particular level of complexity, such as human experienced reality (or the broader experiential realism). For this reason, the God who transcends the experiential realism of human consciousness cannot be studied by humankind as if God were an object (Nürnberger 2016a:6). 'We can only study our own intuition, notion or concept of God' (Nürnberger 2016a:19), which is our expression of religious faith. Nürnberger (2017) states:
If God is the transcendent Source and Destiny of reality, 'he' makes himself known to us through 'his' creation, that is, the world we experience and the sciences explore, including the human spiritual capacity of intuiting and conceptualising the divine. (p. 1)

God cannot be discovered. We simply do not have the correct hermeneutic tools, neither do we have an adequate perspective on the totality of complexity. In this way God is transcendent; God transcends our horizons. But God is also personal. The only possibility in which humanity can have an awareness of God is by such a transcendent God having revealed Godself - an act of self-disclosure (Nürnberger 2016b:21), which becomes the immanent transmission of transcendental information.

As Gregersen suggests, it is this transcendent God who manifests as a human in the person of Jesus Christ (Gregersen 2013:252). God's self-disclosure does not come as a metaphysical proposition (Nürnberger 2016a:3); instead God manifests and reveals Godself in human experienced reality (Nürnberger 2016a:4) as a human. The transcendent God communicates in an intimate language that humanity (and nature) understands - the Word became flesh (Nürnberger 2011b:116-117). To Nürnberger, God's immanence is in no way a contradiction of God's transcendence or vice versa. Through the person of Jesus Christ, the transcendent God communicates to and in a stratum of experiential realism of which the transcendental God is part of already. God as Source and Destiny meets us in the person of Christ (Nürnberger 2016b:xv).

God makes Godself understandable in human language (Nürnberger 2011b:2). Our seemingly innate religious faith is the intuition that reality is derived from a transcendent Source and headed towards a transcendent Destiny, while theology seeks to clarify this intuition' (Van Wyk 2018:1). Faith (religion) expresses the belief that God's personal selfrevelation does not only reveal who God is, but it also informs humanity of its own identity in relation to the ultimate Source and ultimate Destiny (Nürnberger 2016b:52-55). The message essentially conveys God's benevolent nature and God's acceptance of humankind (including nature and all its processes) (Nürnberger 2016b:69-78).

Where science gives us an understanding of how the universe operates, faith helps us understand how we should operate within the context of experiential realism. Faith is the proclamation of the benevolent intentionality of the Source and Destiny of experiential realism (Nürnberger 2016c:4). Nürnberger (2016a) states:

[it is] ... not the task of theology to construct a neat and coherent metaphysical system, which may only exist in our heads but [to] analyse what actually happens in the world we experience. (p. 11)

This is as far as theology needs to go; to appreciate the experiential reality in which it exists, while pointing out 
that meaning is to be found in the call to love God with our entire beings and to love each other as we love ourselves.

\section{Conclusion}

'God does not exist; God is'. Perhaps this is a good way to summarise Nürnberger's description of God. God is, but not as a metaphysical, transcendental God, fixed outside the manifestation and processes of the physical universe. God is part of the creativity of the universe as its ultimate Source and Destiny, neither locked within it, nor excluded from it. It is our intuition that the natural processes have a source and destiny, and therefore the existence of humanity, our awareness, consciousness and being have a role to play in the unfolding complexities of the evolving universe. Viewing God as the ultimate Source and Destiny of a complex universe (of which humankind is a miniscule part) emphasises the wonder of such a God making Godself known in a language that is understood by humankind.

God is immanent, not in the metaphysical narratives of highfalutin theological God-talk, but becomes the immanent God through God's self-revelation in Jesus Christ, who taught that God's Kingdom is to be found not in wishing for extra-worldly heavens, but in the responsible participation in experiential realism by feeding the hungry, clothing the naked, visiting the sick and incarcerated, by finding value in looking at the lilies of the field, the birds of the air ... to find answers to life's difficult questions by gazing at the night sky ... to get lost in the wonder of a transcendent God who sometimes speaks through a gentle breeze.

\section{Acknowledgements Competing interests}

The author declares that he has no competing interests with regard to the writing of this article.

\section{References}

Conradie, E.M., 2012, 'Between vanity and sanity: Review essay on Klaus Nürnberger's "Regaining sanity for the earth", Journal of Theology for Southern Africa 144, 126-143.

Conradie, E.M., 2013, 'A semiotic notion of transcendence', Studia Historiae Ecclesiasticae 39(Supplement), 39-54.

Dawkins, R., 2006, The God delusion, Bantam Press, London.

Durand, F., 2017, 'Naledi: An example of how natural phenomena can inspire metaphysical assumptions', HTS Theological Studies 73(3), 1-9. https://doi.org/ 10.4102/hts.v73i3.4507

Gould, S.J., 2002, Rocks of ages: Science and religion in the fullness of life, Ballantine Books, New York.

Gregersen, N.H., 2013, 'Deep incarnation and kenosis: In, with, under, and as: A response to Ted Peters', Dialog 52(3), 251-262. https://doi.org/10.1111/dial.12050

Hick, J., 1997, 'Transcendence and truth', in D.Z. Phillips \& T. Tessin (eds.), Religion without transcendence?, pp. 41-59, Macmillan Press, London.

Kauffman, S.A., 2008, Reinventing the sacred: A new view of science, reason and religion, Perseus Books, New York.

Moltmann, J., 1985, God in creation, SCM Press, London.

Moltmann, J., 1996, The coming of God: Christian eschatology, SCM Press, London.

Nürnberger, K., 2010, 'Immanent transcendence and radical transcendence: The pivotal issue between a Christian theology and a naturalistic metaphysic', in C.W. du Toit (ed.), Homo transcendentalis? Transcendence in science and religion, pp. 103-127, Research Institute for Theology and Religion, Pretoria.

Nürnberger, K., 2011a, Regaining sanity for the earth, Cluster Publications, Pietermaritzburg.

Nürnberger, K., 2011b, 'Transcendence as the key issue between naturalism and the Christian concept of God: A dialogue with Richard Dawkins, Stuart Kauffman, and Brian Swimme', Ars Disputandi 11, 1-23. https://doi.org/10.1080/15665399.2011. 10820046

Nürnberger, K., 2012, 'The "Spirit" and the "groaning of creation" in Romans 8 seen against the background of modern science', Scriptura 109, 53-66. https://doi. org/10.7833/109-0-124

Nürnberger, K., 2015, 'Dust of the ground and breath of life (Gen 2:7): The notion of "life" in ancient Israel and emergence theory', in D. Evers, M. Fuller \& A. Jackelén (eds.), Issues in science and theology: What is life?, pp. 101-116, Springer (eds.), Issues in science

Nürnberger, K., 2016a, Faith in Christ today: Invitation to systematic theology, volume 1, Cluster Publications, Pietermaritzburg.

Nürnberger, K., 2016b, Faith in Christ today: Invitation to systematic theology, volume 2, Cluster Publications, Pietermaritzburg.

Nürnberger, K., 2016c, 'The concept of revelation in terms of the evolution of consciousness', HTS Theological Studies 72(4), 1-10. https://doi.org/10.4102/hts. v72i 4.3430

Nürnberger, K., 2017, 'Eschatology as a manifestation of human uniqueness: Human vision, biblical revelation and divine agency', HTS Theological Studies 73(7), 1-14. https://doi.org/10.4102/hts.v73i3.4341

Van Wyk, T., 2018, 'A study on systematic theology', In die Skriflig 52(1), 1-3. https:// doi.org/10.4102/ids.v52i1.2329

Veldsman, D., 2013, 'The bio-century challenge: Life in a holistic context. In conversation with Cornel du Toit', Studia Historiae Ecclesiasticae 39(Supplement), 23-38. 